\title{
Plio-Quaternary Sandy Deposits and Microbial Buildups at the Southern Marmara Shelf Near Shoreface Area, Turkey
}

\author{
Denizhan Vardar, ${ }^{1, *}$, Hande Aykurt $\operatorname{Vardar}^{2}$ \\ ${ }^{1}$ Istanbul University, Institute of Marine Science and Management, Department of Marine Geology and Geophysics, \\ FATIH, ISTANBUL-TR \\ ${ }^{2}$ Istanbul University Engineering Faculty, Department of Geophysical Engineering, AVCILAR, ISTANBUL-TR
}

\begin{abstract}
Understanding the formation and evolution mechanism of the sandy deposits plays key role to define the hydrodynamics of the shelves and coasts. The barrier islands determined from high resolution chirp seismic reflection profiles, were started to deposit on the boundary (SB) that characterized by the lowstand stages of global sea level in the southern Marmara shelf near shoreface area. The unit haslost its activity at $55 \mathrm{~ms}, 60 \mathrm{~ms}$ depth in Erdek Bay, at $55 \mathrm{~ms}$ in Bandırma Bay, at $61 \mathrm{~ms}$ front of the Kocasu River. According to global sea level curves, this unit was evolved between 11000-11500 BP and10450-10150 BP. The geometrical situation and internal reflection character of these units indicate the balance between fluvial sediment transportation, marine intrusion and current systems in the study area. Belkis Isthmus that connects the Kapıdağ Peninsula to the mainland occurred synchronously with same process that formed the barrier islands. Bioherm structures were formed on the barrier islands and some of the bioherm's uppermost surface is reached to $1 \mathrm{~m}$ below the sea floor. Bioherm structures are composing from organisms; formation and evolution depend on various stress factors. Barrier islands provide nutritional source to bioherms. Since these structures occur in a limited area, the development should be controlled by secondary factors. Biogenic gas determined from seismic sections closed to bioherm structures, probably plays the secondary role. Addition to this, during the forming and the growing of bioherms, Marmara Islands (Pasalimanı, Avşa, Marmara Islands) and Imralı Island were possibly control the currents and the flooding in the study area and provided convenient environment to these structures evolution.
\end{abstract}

Keywords: Sandy deposits, microbial buildups, seismic profiles, bioherm structures, Southern Marmara Shelf

\section{Introduction}

The morphology, geology and underlying stratigraphy of a coastal system has been related to the near-shore dynamics and longerterm expressions of shoreline variations (Schwab et al., 2000; McNinch, 2004; Harris et al., 2005; Browder and McNinch, 2006; Schupp et al., 2006; Houser et al., 2008; Hapke et al., 2010b; Houser, 2012). The modifications of dunes and beaches, such as beach replenishment, increase the elevation, grade, and width of a beach, though their impacts on morphologic behavior are often poorly understood (Thornton et al., 2006; Park et al., 2009). The primary aim of this paper to map the geometry and the distribution of the buried barrier islands and microbial buildup (bioherm) at the southern Marmara shelf near offshore

area, define these morphological structures by seismic stratigraphic principles and discuss the integration with the relative global sea level changes that affect the study area.

Barrier islands which found along $13 \%$ of the world's coastlines (Dean and Dalrymple, 2002), are elongated accumulations of sediment. Generally, the barrier islands are representing by the time-integrated deposition of past beach, backshore and dune environments, eroding layers deposited by shelf and land-based processes (Riggs et al., 1995). Such as most coastal depositional environments, the evolution of the barrier islands is controlled by 
the balance between sediment accumulation and sediment accommodation, which is closely related to relative sea-level.

The formation of the barrier islands defined as aggradational, transgressive, and regressive styles (Fig 1) (Galloway and Hobday, 1983). Aggradational barriers form when the rate of sediment accumulation equals the rate of creation of sediment accommodation and the estuarine and ocean shorelines remain stationary through time forming a thick lithesome. Transgressive barriers form when the rate of sediment accumulation is less than the rate of creation of sediment shorelines of these islands migrate landward through time by wave erosion and overwash, forming a thin and low-elevation coastal lithesome. Regressive barriers form when the rate of sediment accumulation exceeds the rate of creation of sediment accommodation and the ocean shoreline progrades seaward while the estuarine shoreline remains relatively stable forming a wide and high-elevation barrier with ridge and swale topography.

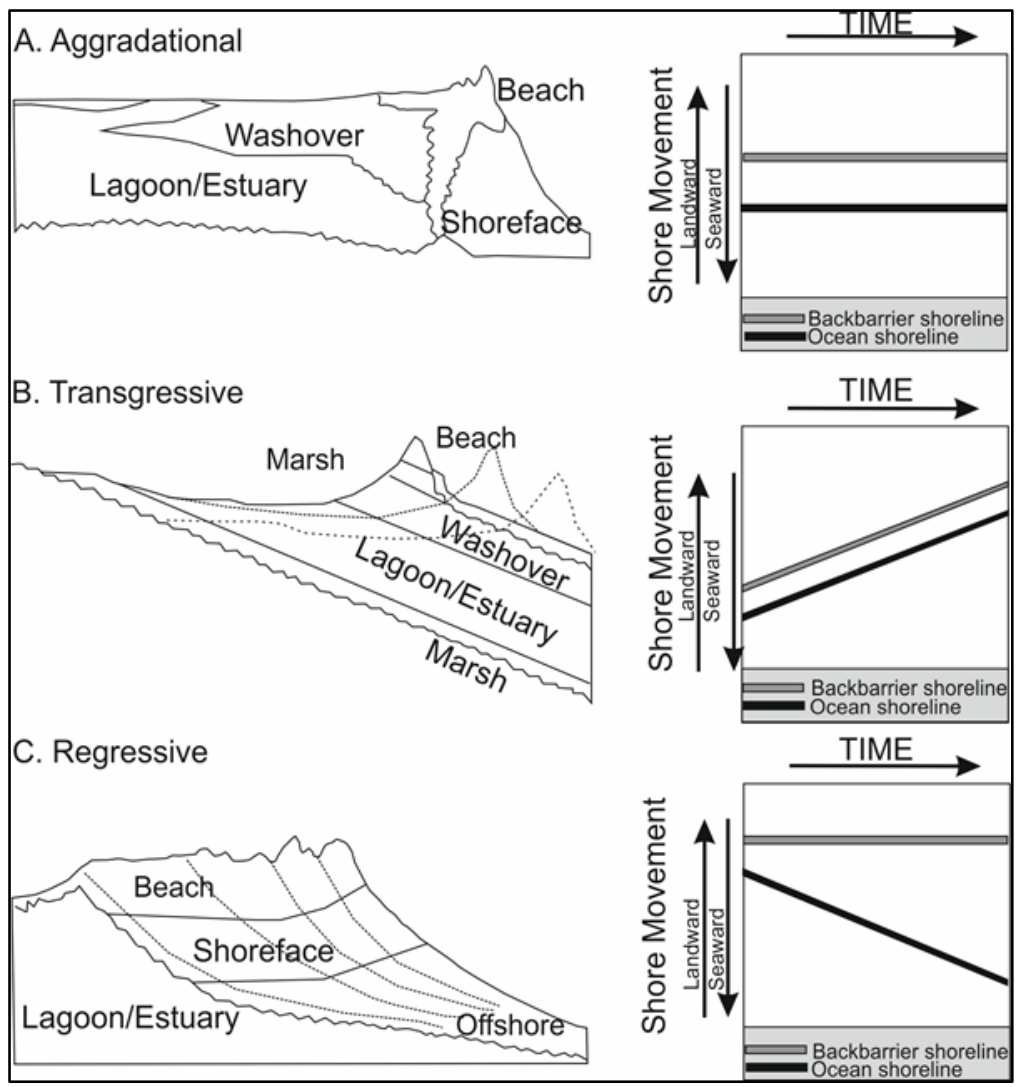

Fig 1. Models of aggradational (A), transgressive (B), and regressive (C) barrier island evolution (after Galloway and Hobday, 1983).

The differences in architecture and the variety of structural, depositional, and compositional features observed microbial buildups have been also explained in terms of global climate and paleoceanographic collocation on the shelves. The analysis of the different reef building styles defined by the types of associated facies and by the early diagenetic features can provide information on the climatic and spatial conditions of the primary depositional setting. Since the relative development of the main reef-building components and their evolution within the reef communities appear to reflect the dominant physico-chemical factors of the environment. In an attempt to establish clear descriptive terms, Cumings and Shrock (1928) proposed bioherm for "a dome-like, lens-like 
or other circumscribed mass built exclusively or mainly by sedentary organisms and enclosed in normal rock of different lithological character'.

In Aksu et al. (1999); shore-parallel, NW-SE trending depositional mounds which interpreted as barrier islands, were mapped at the Kapıdağ Peninsula which extends to Marmara Island and at the east and west of Imralı Island. The Internal reflections within delta packages that determined in Aksu et al. (1999), were laterally traced into the barrier islands thereby the authors were suggesting the barriers were successively active throughout the time of deltaic sedimentation, perhaps as delta-front sands were reworked by waves.

The bioherm structures in the different parts of the Marmara Sea were outlined in some previous studies (Aksu et al., 1999; Yaltırak et al., 2002; Çağatay et al., 2009), defined as algal-serpulid bioherm and pointed that were formed on the barrier islands and deltas during the Holocene (Aksu et al., 1999, Yaltırak et al., 2002). In Çağatay et al. 2009, the authors were characterized the stratigraphy of the bioherm structures with 1.5 meter length $\mathrm{C} 1$ core where picked from İstanbul Çekmece shelf nearly -73 meter depth and make $\delta 18 \mathrm{O}$ and $\delta 13 \mathrm{C}$ analysis.

And they conclude an increasing salinity in the Marmara Sea.

\section{Study Area}

The southern shelf of the Sea of Marmara covers a broader area (4194 $\mathrm{km} 2$ ) compared to the northern one and its average width is $20 \mathrm{~km}$ (Gazioğlu et al. 2002) (Fig. 3a). Along the 290$\mathrm{km}$ long southern coasts, the study area covers three sub-basins, namely Erdek, Bandirma and Gemlik, lined up between the Karabiga Promontory in the west and Gemlik Village in the east. The steep and uplifted shores observed between the Kapıdağ Peninsula and Armutlu Peninsula, are mostly fault-controlled. Kapıdağ peninsula connects to mainland via Belkis Isthmus.

The surface sediments covering the study area (Fig 2) are composed of reflecting the effect of the strong riverine input (Kocasu, Gonen and Biga) and carbonate-rich biogenic sediments (Ergin et al. 1997; Balkıs and Cagatay, 2001; Ünlü and Alpar 2006). Erdek, Bandırma and Gemlik bays represent semi-isolated small sedimentary environments within the southern shelf and are dominated by fine-grained sediments. Kocasu River's drainage area 21611 $\mathrm{km} 2$, average discharge $150.6 \mathrm{~m} 3 \mathrm{~s}-1$, suspended sediment discharge 1986x1000 t yr1 (Aksu et al. 1999). Gönen River's drainage area $1193 \mathrm{~km} 2$, average discharge $16.0 \mathrm{~m} 3 \mathrm{~s}-1$, suspended sediment discharge 78,000 t $\mathrm{yr}-1$ (Aksu et al. 1999). Biga Rivers drainage area $2096 \mathrm{~km} 2$, average discharge $18.6 \mathrm{~m} 3 \mathrm{~s}-1$, suspended sediment discharge 97,000 t yr-1 (Aksu et al. 1999).

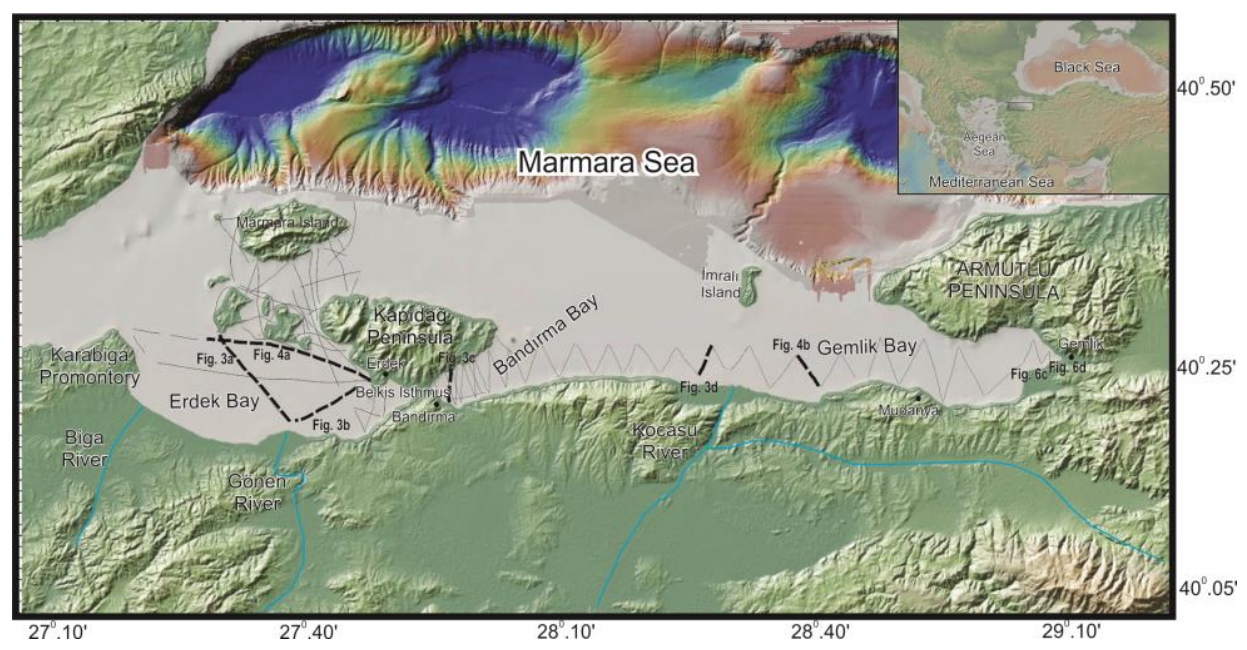

Fig 2. Location map of the study area and high resolution seismic profiles 


\section{Material and Method}

New high-resolution chirp seismic data were collected in 2010-2011 (total 1000 km) (Fig. 2) by Bathy 2010P'M Chirp sub-bottom profiler and bathymetric echo sounder which provides high performance sub-bottom survey capability usually for shallow inland waterways by providing algorithms for peak signal detection. The system uses 4 transducers, each producing 2-8 $\mathrm{kHz}$ simultaneous chirp signals, in array configurations to provide full power capability. The power level, sweep bandwidth and detection threshold was adjusted automatically during the survey. The transmit pulse repetition rate was $1 \mathrm{~Hz}$ dependent on the depth range $(150 \mathrm{~m})$ and also on the selected pulse length which is short enough in order to resolve thin layers covering the sub-bottom strata. The depth resolution was about 0.2 meters with 5060 meters of bottom penetration, but mainly depending on the bottom type. The speed of the research boat was set to $7.0-7.5 \mathrm{~km} / \mathrm{h}$ during the survey. The ship's position and heading provided with a Magellan Proflex 500 scientific GPS were stored in data files. Following some basic data processing sequences such as gain recovery and filtering using Kogeo Seismic Toolkit 2.7, the seismic sections were interpreted with the aid of seismic reflection interpretation software "The Kingdom Suite" donated by "Seismic Micro Technology". The travel times were converted to depth values below the present mean sea level using the typical interval velocities of 1500 and 1700 $\mathrm{m} / \mathrm{s}$, which have been found to be appropriate for the water column and near-surface siliciclastic sediments (Eriş et al. 2007), respectively.

\section{Results}

Barrier islands are determined by internal seismic reflection that characterized by continuous, sub-horizontal, gently landward dipping (Fig 3 a, b, c, d; Fig 4a,b) in the seismic reflection profiles. The unit formed on the sequence boundary surface (SB) that related with last lowstand sea level (Fig 3 a, b, c, d; Fig $4 a, b)$. The upper surface depth of the unit at 55 $\mathrm{ms}(\sim 45 \mathrm{~m})$ in the SE-NW direction seismic reflection profiles in front of the Gönen River (Fig 3a). The thickness was thinning to the coastal area and immediately thicken controlled by normal fault (Fig 3a). The average thickness of the barrier island is $6 \mathrm{~ms}(\sim 5 \mathrm{~m})$. Although the continuity of the unit was masked by the gas (Fig 4a), the observable part's width is approximately $2000 \mathrm{~m}$. Between Kapıdağ Peninsula and the mouth of the Gönen River (Fig 3b) the upper surface of the barrier island at $60 \mathrm{~ms}(\sim 55 \mathrm{~m})$ and ended by fault at the NW part of the bay. The average width and thickness is respectively $110 \mathrm{~m}, 2 \mathrm{~ms}(\sim 1.7 \mathrm{~m})$. In the Bandirma Bay the unit is observed at the NW side of the bay and the upper surface is at $55 \mathrm{~ms}(\sim 45 \mathrm{~m})$. The average thickness of the unit is $8 \mathrm{~ms}(\sim 6.6 \mathrm{~m})$ and get thinner to the north. The southern edge of the unit is steeper than northern edge and the width is approximately $1300 \mathrm{~m}$ (Fig 3c). In front of the Kocasu River, average thickness of the unit is $10 \mathrm{~ms}(\sim 8 \mathrm{~m})$ and the upper surface at $-61 \mathrm{~ms}$ $(50 \mathrm{~m})$. The continuity of the unit was masked by the gas (Fig 3d), the observable part's width is approximately $4500 \mathrm{~m}$. The bioherm structures were determined as a "dome-like" and "lens shaped" seismic reflection character (Fig. 4a, b) and these structures began to accumulate on the uppermost surface of the barrier island (Fig. 4a, b). The transgression period seismic package thickness that deposited on the unconformity surface is approximately $13 \mathrm{~ms}(10 \mathrm{~m})$ for whole study area. The bioherm structures were determined as a "dome-like" and "lens shaped" seismic reflection character (Fig. 4a, b) and these structures began to accumulate on the uppermost surface of the barrier island (Fig. 4a, b). 

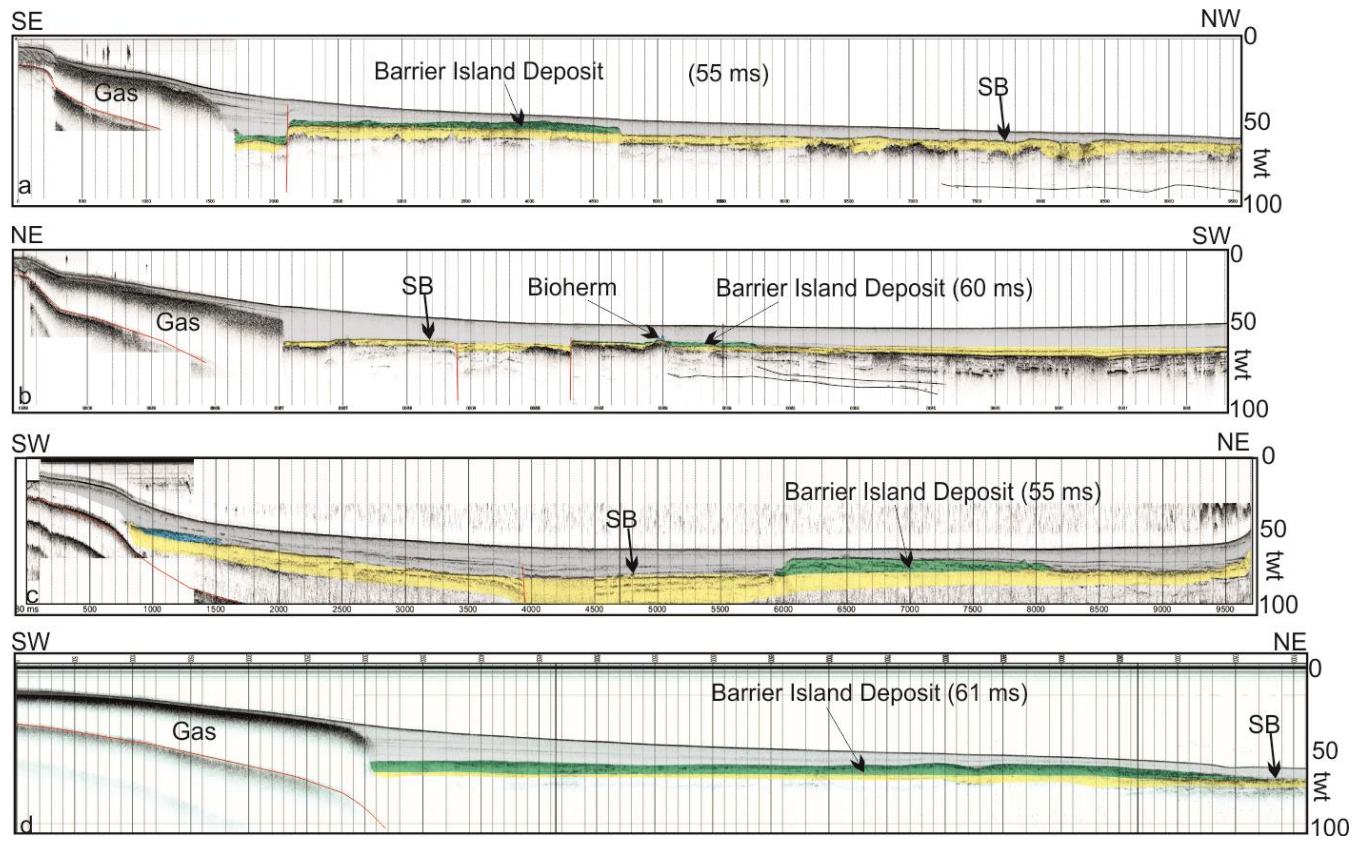

Fig 3 a SE-NW seismic section at the Erdek Bay, b NE-SE seismic section at the Erdek Bay c SWNE seismic section at the Bandırma Bay d SE-NW seismic section at the front of the Kocasu River (See Fig 2 for locations)

The transgression period seismic package thickness that deposited on the unconformity surface is approximately $13 \mathrm{~ms}(10 \mathrm{~m})$ for whole study area. In the Erdek Bay, bioherm structures are bulked at the southern shoreface area of the Pasalimanı Island (Fig 4a). Despite of the barrier island deposits still in the area the bioherm structures are immediately disappear

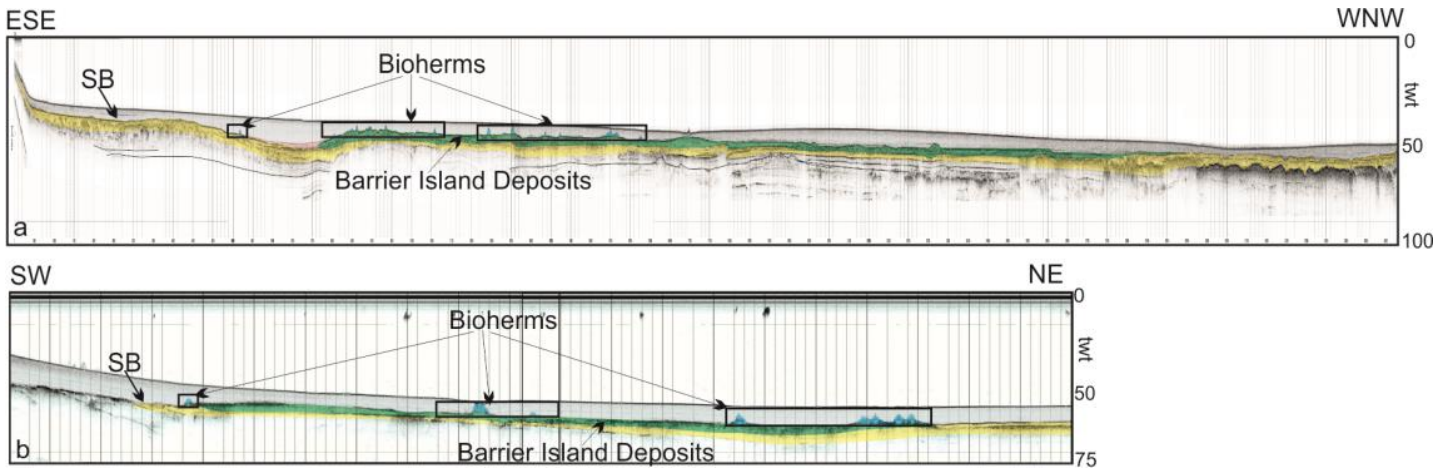

Fig 4 a ESE-WNW seismic section at the Erdek Bay, b SW-NE seismic section at the front of the Kocasu River (See Fig 2 for locations)

\section{Discussion and Conclusion}

The all buried barrier islands in the study area were deposited on the unconformity relatively to the west. The uppermost surface of the bioherm is reached to $1 \mathrm{~m}$ below the sea floor. The eastern side of the Kocasu River and the southeast offshore side of the Imralı Island is the only area that bioherms could be observed. (Fig 4b) and the upper surface is reached to $1 \mathrm{~m}$ below the sea floor. conformity surface (SB) that characterized with lowstand sea level. This unit was starting to deposit during the marine intrusion to the study area at 11000-11500 BP (Fig 5).Morphological 
character of the unit in the seismic reflection profiles corresponds with aggradational model given by Galloway and Hobday (1983). Buried barrier islands expanded to wide area at the right and left side the Kocasu River offshore, narrow area at the northern side of the Bandirma Bay (Fig 6). In the Erdek Bay, unit is located between mouth of the Gonen River and Belkıs Isthmus and southern side of the Pasalimanı Island towards to Kapıdağ Peninsula (Fig. 6). The barrier islands geometry is relatively S-E direction (Fig 6). The geometrical situation and internal reflection character of these units indicate the balance between fluvial sediment transportation, marine intrusion and current systems in the study area. According to sea level curves given by Stanford et al. (2011), barrier islands lost its depositional activity at approximately at 10450-10150 BP (Fig 6). During the initial stage of the marine intrusion, barrier islands formed in one piece but after lost its activity current and fluvial erosion comminutes it. The differences of the uppermost surface depths probably arise from erosional processes or regional tectonics given by Vardar et al. (2014). Another interesting result can be derived from the barrier island geometry is Belkis Isthmus that connects the Kapıdağ Peninsula to the mainland occurred synchronously with same process that formed the barrier islands. This isthmus is at the interior part of the Bandirma and Gemlik Bays so that the development continues without being affected by erosion.

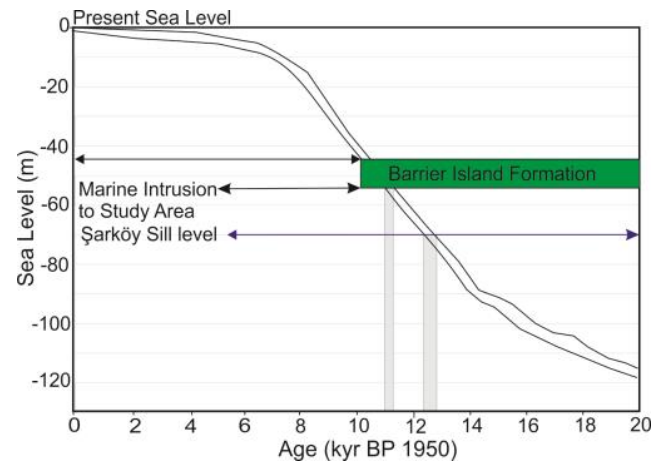

Fig 5. The elevation of the ridges controlling water connections in the Sea of Marmara depicted on the glacio-eustatic sea level changes for the last 20,000 yr BP given by Stanford et al. (2011)

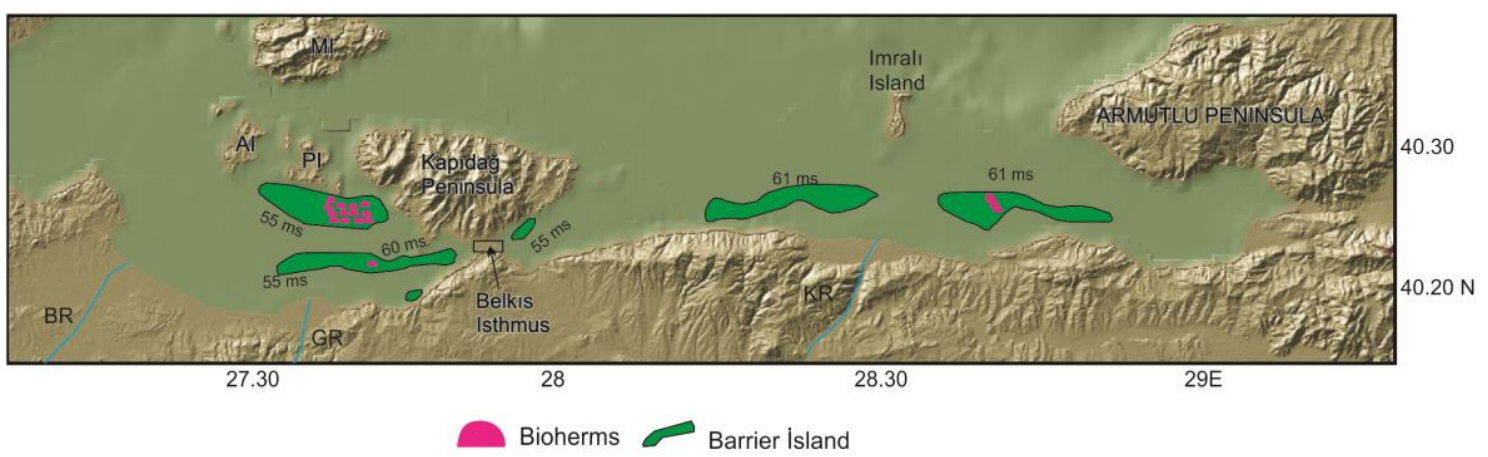

Fig 6. The distribution and geometry of barrier islands and bioherm strucutrues in the study are, AI Avşa Island, PI Pasalimanı Island, MI Marmara Island, BR Biga River, GR Gemlik River, KR Kocasu River

\section{Acknowledgement}

This study is supported by the Scientific Research Fund of Istanbul University under the projects ÖNAP 2914 and TP 6527. The author wish to thank to Sabri Bal and Bülent Şahin for their assistance in field studies. 


\section{References}

Aksu, A. E., Hiscott, R. N., Yaşar, D. (1999) Oscillating Quaternary water levels of the Marmara Sea and vigorous outflow into the Aegean Sea from the Marmara Sea-Black Sea drainage corridor. Marine Geology, 153, 275-302.

Balkıs, N., Çağatay, M.N. (2001) Factors controlling metal distributions in the surface sediments of the Erdek Bay, Sea of Marmara, Turkey. Environment International 27: 1-13

Browder, A.G., McNinch, J.E. (2006) Linking framework geology and near shore morphology: correlation of paleo-channels with shore-oblique sandbars and gravel outcrops. Marine Geology 231, 141-162.

Cumings, E. R., Shrock, R. R. (1928) Niagaran coral reefs of Indiana and adjacent States and their stratigraphic relations. Bulletin Geological Society America, 39, 579-620.

Çağatay, M. N., Eriş, K., Ryan, W. B. F., Sancar, Ü., Polonia, A., Akçer, S:, Biltekin, D., Gasperini, L., Görür, N., Lericolais, G., Bard E. (2009) Late Pleistocene-Holocene evolution of the northern shelf of the Sea of Marmara. Marine Geology 265, 87-100.

Dean, R.G., Dalrymple, R.A. (2002) Coastal Processes with Engineering Applications. Cambridge Univ. Press, Cambridge.

Galloway, W.E., Hobday, D.K. (1983) Terrigenous Clastic DepositionalSystems. Springer, Berlin, 489 pp.

Ergin, M., Kazanci, N., Varol, B., Ileri, Ö., Karadenizli, L. (1997) Sea-level changes and related depositional environments on the southern shelf. Mar Geo 140: 391-403

Eriş, K. K., Ryan, W. B. F., Cagatay, M.N., Sancar, U., Lericolais, G., Menot, G., Bard, E. (2007) The timing and evolution of the post-glacial transgression across the Sea of Marmara shelf south of Istanbul. Mar Geo 243: 57-76

Gazioğlu, C., Gökaşan, E., Algan, O., Yücel, Z.Y., Tok, B., Doğan, E. (2002) Morphologic features of the Marmara Sea from multibeam data. Marine Geology 190: $397-420$

Hapke, C.J., Lentz, E.E., Gayes, P.T., McCoy, C.A., Hehre, R.E., Schwab, W.C., Williams, S.J., (2010) A review of sediment budget imbalances along Fire Island, New York:
Can nearshore geologic framework and patterns of shoreline change explain the deficit? Journal of Coastal Research 26, 510-522

Harris,M.S., Gayes, P.T., Kindinger, J.L., Flocks, J.G., Krantz, D.E., Donovan, P. (2005) Quaternary geomorphology and modern coastal development in response to an inherent framework: an example from Charleston, South Carolina. Journal of Coastal Research 21, 49-64.

Houser, C., Hapke, C., Hamilton, S. (2008) Controls on coastal dune morphology, shoreline erosion, and barrier island response to extreme storms. Geomorphology 100, 223-240.

Houser, C. (2012) Alongshore variation in the morphology of coastal dunes: implications for storm response. Geomorphology 1173174, 1-16.

McNinch, J.E. (2004) Geologic control in the nearshore: shore-oblique sandbars and shoreline erosional hotspots, Mid-Atlantic Bight, USA. Marine Geology 211, 121-141.

Park, J.Y., Gayes, P.T., Wells, J.T. (2009) Monitoring beach renourishment along the sediment-starved shoreline of Grand Strand, South Carolina. Journal of Coastal Research 25, 336-349.

Riggs, S.R., Cleary, W.J., Snyder, S.W. (1995) Influence of inherited geologic framework upon barrier beach morphology and shoreface dynamics. Marine Geology 126, 213-234.

Schupp, C.A., McNinch, J.E., List, J.H. (2006) Nearshore shore-oblique bars, gravel outcrops, and their correlation to shoreline change. Marine Geology 233, 63-79.

Schwab, W.C., Thieler, E.R., Allen, J.R., Foster, D.S., Swift, B.A., Denny, J.F. (2000) Influence of inner-continental shelf geologic framework on the evolution and behavior of the Barrier-Island System between Fire Island Inlet and Shinnecock Inlet, Long Island, New York. Journal of Coastal Research 16, 408-422.

Stanford, J.D., Hemingway, R., Rohling E. J., Challenor, P.G., Medina-Elizalde, M., Lester, A.J. (2011) Sea-level probability for the last deglaciation: A statistical analysis of far-field records. Global and Planetary Change 79 (3-4): 193-203 
Ünlü, S., Alpar, B. (2006) Distribution and sources of hydrocarbons in surface sediments of Gemlik Bay (Marmara Sea, Turkey). Chemosphere 64: 764-777

Thornton, E.B., Sallenger, A., Conforto Sesto, J., Egley, L., McGee, T., Parsons, R. (2006) Sand mining impacts on long-term dune erosion in southern Monterey Bay. Marine Geology 229, 45-58.
Vardar, D., Öztürk, K., Yaltırak, C., Alpar, B., Tur, H. (2014) Late Pleistocene-Holocene evolution of the southern Marmara shelf and sub-basins: middle strand of the North Anatolian fault, southern Marmara Sea, Turkey. Marine Geophysical Researches, DOI 10.1007/s11001-013-9210-8.

Yaltırak, C. (2002) Tectonic evolution of the Marmara Sea and its surroundings. Marine Geology, 190,493-529. 